\title{
Aeromonas shigelloides (Bader) Ewing et al.: a Proposal That It BeTransferred to the Genus Vibrio
}

\author{
MARGARET S. HENDRIE, J. M. SHEWAN, and M. VÉRON
}

Torry Research Station, Aberdeen, Scotland, and Institut Pasteur, Paris, France

\begin{abstract}
A comparison of the data now available on the microorganism variously called C27, Aeromonas shigelloides, Pseudomonas shigelloides, Pseudomonas michigani, Plesiomonas shigelloides, and Fergusonia shigelloides suggests that this organism fits best into the generic description of Vibrio and accordingly should be transferred to this genus as Vibrio shigelloides (Bader) comb. nov.
\end{abstract}

In 1947, Ferguson and his co-workers isolated a motile enteric organism, thought at that time to belong to the Enterobacteriaceae, which contained a major somatic antigen of Shigella sonnei, phase I; they later described this organism in detail as $\mathrm{C} 27(10)$. Since then, organisms similar to or identical with $\mathrm{C} 27$ have been isolated by various workers, mainly from clinical materials in man and animals $(1,2,5$, $12,16-18,24)$.

The taxonomic position of this interesting organism has also been the subject of numerous publications, the most important of which are those by Sakazaki et al. (17), Ewing and Johnson (8), Ewing et al. (7), Habs and Schubert (13), Sebald and Véron (19), and Eddy and Carpenter (6).

Early workers $(10,18)$ clearly considered it to be an anaerogenic, motile paracolon, and Ferguson and Henderson (10) reported $\mathrm{C} 27$ to be "apparently amphitrichous." Most workers now agree that the organism is a polar flagellated, gram-negative rod, oxidase- and catalasepositive, which ferments carbohydrates and which could be placed in either the genus Aeromonas or the genus Vibrio.

Bader (2) had shown that organisms he had isolated from dog feces possessed a major antigen of Shigella sonnei and were polarly flagellated, and he proposed the name Pseudomonas shigelloides for these organisms, mainly because they were gram-negative rods with lophotrichous flagellation, fermented glucose anaerogenically, failed to ferment lactose, but reduced nitrate to nitrite. The clear differentiation between Pseudomonas and Aeromonas was not then understood, and Bader's assignment of the organism to the genus Pseudomonas was justified. Sakazaki et al. (17), in a study of 22 strains including Ferguson's original $\mathrm{C} 27$ cultures, confirmed that the organism was lophotrichous but proposed the name Pseudomonas michigani. Meantime, work was proceeding on the differentiation of the polarly flagellated gram-negative bacilli, usually classified as belonging to Pseudomonas, Aeromonas, or Vibrio $(20-22)$. Ewing and Johnson (8), on the basis of the mode of attack on sugars-fermentative as against oxidative (15)-and of the result of the cytochrome oxidase test [a modification of the Gaby and Hadley (11) technique], concluded that the C27-type organisms should be placed in the genus Aeromonas. Subsequently, Ewing et al. (7) confirmed their opinion that $\mathrm{C} 27$ should be considered an aeromonad and suggested that, since the name Pseudomonas shigelloides for the $\mathrm{C} 27$ organism of Bader (2) was validly published, the specific epithet shigelloides should have precedence over the specific epithet michigani in the name Pseudomonas michigani Sakazaki et al. 1959. Ewing et al. (7) did not discuss the possible assignment of the C27 organism to the genus Vibrio.

In 1962, Habs and Schubert (13) compared several of Bader's C27 strains. They confirmed that on the basis of flagellation and other morphological grounds, these organisms belong to the family Pseudomonadaceae and within this family to the tribe Pseudomonadeae. They excluded them from the genera Pseudomonas, Xanthomonas, and Acetobacter because they decomposed glucose anaerobically and from the genera Protaminobacter, Alginomonas, Mycoplana, Zoogloea, and Halobacterium-all of which fail to attack glucose. Zymomonas, 
Azotomonas, and Photobacterium were also thought to be excluded, leaving only Aeromonas.

Experience with the genus Aeromonas led Habs and Schubert (13) to define the latter as consisting of organisms which were polarly flagellated, gram-negative rods, which attacked glucose anaerobically, with or without gas formation, and which possessed a series of exoenzymes (proteolytic, lipolytic, and amylolytic). The uniformity of the genus Aeromonas thus defined would be lost by including within it the C27 organism, Pseudomonas shigelloides. Moreover, Habs and Schubert exclude them from the genus Vibrio mainly on morphological grounds-the cells were not strictly commashaped, although several strains, but not all, were sensitive to the vibriostatic agent 0/129. Accordingly, they proposed a new genus, Plesiomonas. Meantime, Sebald and Véron (19) had been examining the guanine plus cytosine $(\mathrm{GC})$ ratio of the deoxyribonucleic acid of a series of named Vibrio, Aeromonas, Pseudomonas, Moraxella, and P. shigelloides strains and found that the values for the latter were about $51 \%$, and so different from that found in the genera Pseudomonas (64\%) and Aeromonas $(60 \%)$, that they proposed a new genus, Fergusonia.

Eddy and Carpenter (6), in a further study on Aeromonas, including C27 strains, concluded that the $\mathrm{C} 27$ group could possibly be included in a new family, Vibrionaceae, as the genus Plesiomonas, but that further discussions of the genera and specific subdivision of the new family must await clarification of the relationship of Vibrio to Aeromonas and of their internal relationships.

Véron (23) has similarly proposed that Plesiomonas shigelloides be included, with the genera Vibrio and Aeromonas, in the family Vibrionaceae, a family which should be clearly distinguished from the family Spirillaceae and composed of strict aerobes or microaerophiles.

Morphologically, organisms in the genus Plesiomonas seldom show the comma-shaped rod so characteristic of Vibrio cholerae, the type species of the genus Vibrio. However, other members of the genus, such as $V$. fischeri and $V$. anguillarum, are often very much less comma-shaped than $V$. cholerae, and exclusion from the genus on such morphological grounds as suggested by Habs and Schubert (13) would appear to be doubtful. Moreover, the possession of lophotrichous flagellation as opposed to the single polar flagellum of $V$. cholerae is not sufficient to exclude it from the genus, because $V$. fischeri has also been shown to be lopho- trichous (14). Also, possession of the lysine and ornithine decarboxylases and failure to produce alkaline reaction in arginine medium are not constant features of Vibrio species as asserted by Habs and Schubert (13). Thus, in our hands $V$. anguillarum and $V$. costicolus are both positive in arginine but negative in lysine and ornithine, whereas $V$. fischeri is positive only in lysine (14).

It is our contention that the anaerogenic fermentation of carbohydrates, the sensitivity of many strains to the vibriostatic agent, 0/129, and the values of the GC content, being much lower than those reported for Aeromonas but within the top range for Vibrio, all support the suggestion that the $\mathrm{C} 27$ organism is closer to the genus Vibrio than to the genus Aeromonas. An Adansonian analysis involving over 100 features of $\mathrm{C} 27$ and a large number of both named strains and fresh isolates of species from the genera Aeromonas (including $A$. formicans), Vibrio (including $V$. parahaemolyticus and luminous vibrios), and Pseudomonas showed that C27 had a similarity value of generally 70 to $80 \%$ to the genus Vibrio, but generally less than $60 \%$ to the genus Aeromonas (4).

On the basis of the evidence presented, it is concluded that the organism originally named Pseudomonas shigelloides is closer phenotypically to the genus Vibrio than to Aeromonas, and accordingly we propose it be included in the genus Vibrio as Vibrio shigelloides (Bader) comb. nov.

\section{LITERATURE CITED}

1. Aldová, E., J. Rakovsky, and A. Chovancová. 1966. The microbiological diagnostics of strains of Aeromonas shigelloides isolated in Cuba. J. Hyg. Epidemiol. Microbiol. Immunol. 10:470-482.

2. Bader, R. E. 1954. Über die Herstellung eines agglutinierenden Serums gegen die Rundform von Shigella sonnei mit einem Stamm der Gattung Pseudomonas. Z. Hyg. Infektionskr. 140:450-456.

3. Bain, N., and J. M. Shewan. 1968. Identification of Aeromonas, Vibrio and related organisms, p. 79-84. In B. M. Gibbs and D. A. Shapton (ed.), Identification methods for microbiologists, part B. Academic Press Inc., New York.

4. Bain, N., M. E. Taylor, and J. M. Shewan. 1965. Some preliminary data on a study of the Vibrio and allied genera. Spisy Prirodoved. Fak. Univ. Brne 7:Series K, 298-299.

5. Cooper, R. G., and G. W. Brown. 1968. Plesiomonas shigelloides in South Australia. J. Clin. Pathol. 21:715-718.

6. Eddy, B. P., and K. P. Carpenter. 1964. Further studies on Aeromonas. II. Taxonomy of Aero- 
monas and C27 strains. J. Appl. Bacteriol. 27:96-109.

7. Ewing, W. H., R. Hugh, and J. G. Johnson. 1961. Studies on the Aeromonas group. Communicable Disease Center, Atlanta.

8. Ewing, W. H. and J. G. Johnson. 1960. The differentiation of Aeromonas and C27 cultures from Enterobacteriaceae. Int. Bull. Bacteriol. Nomencl. Taxon. 10:223-230.

9. Ferguson, W. W., M. Branston, G. L. McCallum, and M. J. Carlson. 1947. Rapid identification of Shigella in a public health laboratory. J. Lab. Clin. Med. 32:349-359.

10. Ferguson, W. W., and N. D. Henderson. 1947. Description of strain C27: a motile organism with the major antigen of Shigella sonnei phase I. J. Bacteriol. 54:179-181.

11. Gaby, W. L. and C. Hadley. 1957. Practical laboratory test for the identification of Pseudomonás aeruginosa. J. Bacteriol. 74:356-358.

12. Geizer, E., K. Kopecky, and E. Aldová. 1966. Isolation of Aeromonas shigelloides in a child. J. Hyg. Epidemiol. Microbiol. Immunol. 10:190-194.

13. Habs, H., and R. H. W. Schubert. 1962. Über die biochemischen Merkmale und die taxonomische Stellung von Pseudomonas shigelloides (Bader). Zentralbl. Bakteriol. Parasitenk. Infektionskr. Abt. I. Orig. 186:316-327.

14. Hendrie, M. S., W. Hodgkiss, and J. M. Shewan. 1970. The identification, taxonomy and classification of luminous bacteria. J. Gen. Microbiol. 64:151-160.

15. Hugh, R., and E. Leifson. 1953. The taxonomic significance of fermentative versus oxidative metabolism of carbohydrates by various gram negative bacteria. J. Bacteriol. 66:24-26.
16. Paucková, V., and A. Fukalová. 1968. Occurrence of Aeromonas hydrophila and Aeromonas shigelloides in faeces. Zentralbl. Bakteriol. Parasitenk. Infektionskr. Abt. I. Orig. 206: 212-216.

17. Sakazaki, R., S. Namioka, R. Nakaya, and H. Fukumi. 1959. Studies on the so called paracolon C27 (Ferguson). Jap. J. Med. Sci. Biol. 12:353-363.

18. Schmid, E. E., T. Velaudapillai, and G. R. Niles. 1954. Study of paracolon organisms with the major antigen of Shigella sonnei, form I. J. Bacteriol. 68:50-52.

19. Sebald, M., and M. Véron. 1963. Teneur en Bases de l'ADN et classification des vibrions. Ann. Inst. Pasteur 105:897-910.

20. Shewan, J. M. 1963. The differentiation of certain genera of gram negative bacteria frequently encountered in marine environments, 499-521. In C. H. Oppenheimer (ed.), Symposium on marine microbiology. Charles C Thomas, Publisher, Springfield, Ill.

21. Shewan, J. M., G. Hobbs, and W. Hodgkiss. 1960. A determinative scheme for the identification of certain genera of gram negative bacteria, with special reference to the Pseudomonadaceae. J. Appl. Bacteriol. 23:379-390.

22. Shewan, J. M., W. Hodgkiss, and J. Liston. 1954. A method for the rapid differentiation of certain non-pathogenic asporogenous bacilli. Nature (London) 173:208.

23. Véron, M. 1965. La position taxonomique des Vibrio et de certainés bacteries comparables. C. R. Acad. Sci. Paris 261:5243-5246.

24. Winton, F. W. 1968. Plesiomonas shigelloides: an unusual isolate from faeces. J. Pathol. Bacteriol. 95:562-567. 